\title{
Vacuolization in Myeloid and Erythroid Precursors in a Child with Menkes Disease
}

\author{
Menkes Hastalıkı Bir Çocukta Myeloid ve Eritroid Öncüllerde Vaküolizasyon
}

(D) Seçil Sayın, (D) Şule Ünal, (D) Mualla Çetin, (D) Fatma Gümrük

Hacettepe University Faculty of Medicine, Department of Child Health and Diseases, Unit of Hematology, Ankara, Turkey
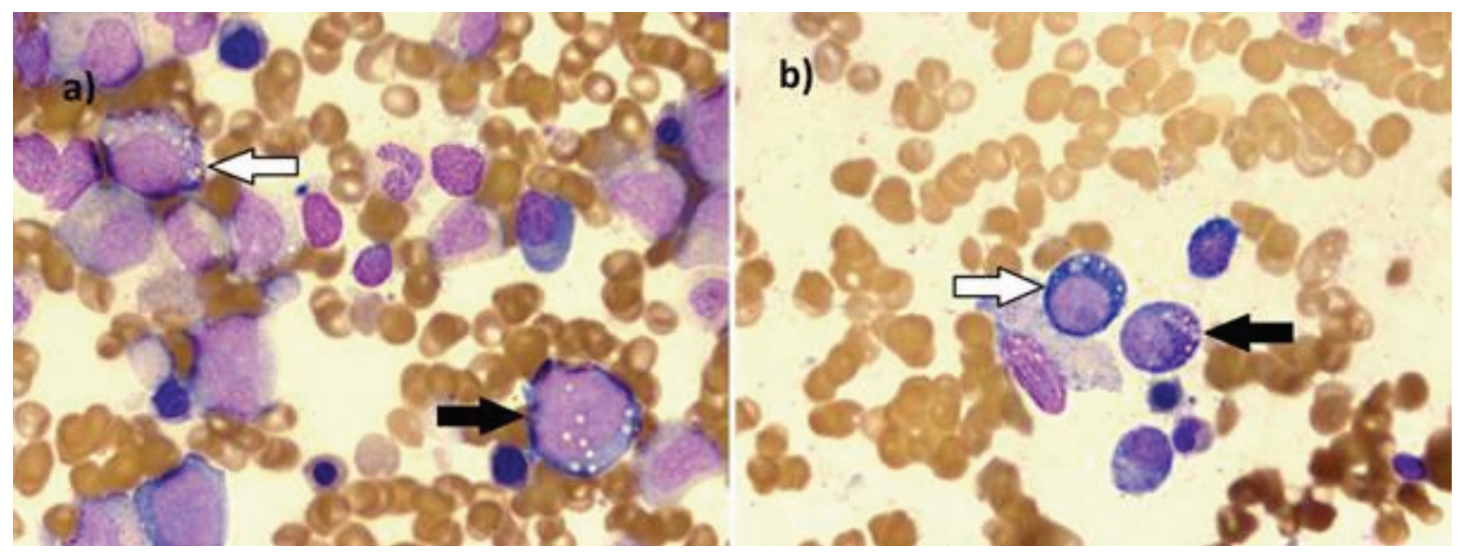

Figure 1. Bone marrow aspiration smears: a) cytoplasmic vacuolization in myeloid precursors (white arrow) and erythroid precursors (black arrow); b) cytoplasmic vacuolization in myeloid precursors (black arrow) and erythroid precursors (white arrow). May-Grünwald Giemsa stain, original magnification 100x.

A 5-year-old boy who was in follow-up with a clinical and biochemical diagnosis of Menkes disease (MD) since 10 months of age was admitted with diarrhea. On examination he had a characteristic cherubic face, hypopigmented and sparse hair, hepatosplenomegaly, and hypotonia with brisk deep tendon reflexes. A complete blood count revealed the following: hemoglobin, $5.5 \mathrm{~g} / \mathrm{dL}$; hematocrit, 16.2\%; red blood cells, 1.69×1012/L; mean corpuscular volume, $95.8 \mathrm{fL}$; mean corpuscular hemoglobin, $32.3 \mathrm{pg}$; red blood cell distribution width, 19.2\%; white blood cells, 2.2×109/L; and platelet count, 157x109/L. Serum vitamin B12 level was 575 pg/mL. Serum copper level was $81 \mu \mathrm{g} / \mathrm{dL}$ and serum zinc level was $152 \mu \mathrm{g} /$ dL. Peripheral blood smear revealed 34\% polymorphonuclear leukocytes, 62\% lymphocytes, and 4\% monocytes. Bone marrow examination revealed normocellular marrow with megaloblastic changes and widespread cytoplasmic vacuolization in myeloid and erythroid progenitors (Figure 1).

Menkes disease is a neurodegenerative disorder due to mutations in the ATP7A gene, which ends with deficiency of copper-dependent enzymes [1].

Cytoplasmic vacuoles of myeloid and erythroid lineages have been described in patients with copper deficiency [2], Pearson syndrome [3], and acute alcoholic intoxication [4]. There have also been reports of megaloblastic changes in copper deficiency [2]. Herein, we exhibited both erythroid and myeloid vacuolizations and severe megaloblastic changes together in a patient with MD. All of these morphological findings in our patient were attributed to copper deficiency.

๑Copyright 2019 by Turkish Society of Hematology

Turkish Journal of Hematology, Published by Galenos Publishing House

口7y

Hacettepe University Faculty of Medicine, Department of Child Health and Diseases, Unit of Hematology,

Received/Geliş tarihi: March 18, 2018 Ankara, Turkey

Phone : +903123055000

E-mail : drsecilgonen@hotmail.com ORCID-ID: orcid.org/0000-0001-6581-6121 
Keywords: Menkes disease, Copper deficiency, Vacuolization, Bone marrow

Anahtar Sözcükler: Menkes hastalığı, Bakır eksikliği, Vaküolizasyon, Kemik iliği

Informed Consent: Received.

Conflict of Interest: The authors of this paper have no conflicts of interest, including specific financial interests, relationships, and/or affiliations relevant to the subject matter or materials included.

\section{References}

1. Kaler SG, Holmes CS, Goldstein DS, Tang J, Godwin SC, Donsante A, Liew CJ, Sato $\mathrm{S}$, Patronas N. Neonatal diagnosis and treatment of Menkes disease. N Engl J Med 2008;358:605-614.

2. Tamura $\mathrm{H}$, Hirose $\mathrm{S}$, Watanabe $\mathrm{O}$, Arai $\mathrm{K}$, Murakawa $\mathrm{M}$, Matsumura $\mathrm{O}$, Isoda $\mathrm{K}$. Anemia and neutropenia due to copper deficiency in enteral nutrition. JPEN J Parenter Enteral Nutr 1994;18:185-189.

3. Topaloğlu R, Lebre AS, Demirkaya E, Kuşkonmaz B, Coşkun $T$, Orhan D, Gürgey $A$, Gümrük $F$. Two new cases with Pearson syndrome and review of Hacettepe experience. Turk J Pediatr 2008;50:572-576.

4. Yeung KY, Klug PP, Lessin LS. Alcohol-induced vacuolization in bone marrow cells: ultrastructure and mechanism of formation. Blood Cells 1988;13:487502. 